Check for updates

Cite this: RSC Adv., 2019, 9, 21826

\title{
Monooxygenase-catalyzed regioselective hydroxylation for the synthesis of hydroxyequols $\uparrow$
}

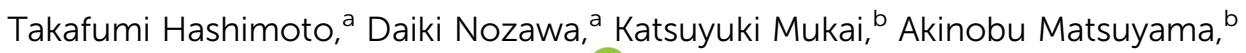 \\ Kouji Kuramochi ${ }^{a}$ and Toshiki Furuya (D) *a
}

Received 24th May 2019

Accepted 9th July 2019

Monooxygenases exhibiting high activity and differing regioselectivity for the dietary isoflavone metabolite equol were discovered among enzymes in the $\mathrm{HpaBC}$ family by a genome mining approach. These enzymes enabled the one-step product-selective synthesis of $3^{\prime}$ - and 6-hydroxyequols from equol and molecular oxygen.

melanogenesis inhibition, collagen synthesis, and vasorelaxation. ${ }^{7}$ Among hydroxyequols, 5-hydroxyequol reportedly exhibits greater antioxidant activity than $(S)$-equol. ${ }^{8} 5$-Hydroxyequol also preferentially binds ER $\alpha$ over ER $\beta$, similar to the natural estrogen $17 \beta$-estradiol in terms of selectivity. ${ }^{9}$ In addition, as hydroxylated analogues are often generated via oxidative metabolism of exogenous compounds in mammals, analysis of the biological activity (including toxicity) of synthetic analogues is important. ${ }^{10}$ Indeed, $(S)$-equol is metabolized to $3^{\prime}$ hydroxyequol and 6-hydroxyequol as the primary products in rat and human liver microsomes. ${ }^{11}$ However, the biological activities of 3'-hydroxyequol and 6-hydroxyequol have yet to be elucidated, in part due to the difficulty of preparing these commercially unavailable compounds. It was reported that $3^{\prime}$ hydroxyequol was synthesized from 2-hydroxybenzyl acetate and aryl-substituted enol ether through Diels-Alder reaction followed by reductive cleavage of the methoxy group. ${ }^{12}$ Oxidants and/or oxidation catalysts that hydroxylate $(S)$-equol might provide a relatively easy and cost-effective approach for the synthesis of hydroxyequols. Although reactions using such compounds are difficult to carry out using chemical methods, biocatalytic methods could enable regioselective hydroxylation in just one step. To date, however, there have been no reports describing enzymes that exhibit such activity for $(S)$-equol.

In this study, we searched for enzymes that can convert $(S)$ equol to hydroxyequols. The two-component flavin-dependent monooxygenase $\mathrm{HpaBC}$ is a candidate for such activity. Enzymes in the HpaBC family consist of a flavin-dependent monooxygenase ( $\mathrm{HpaB})$ and an $\mathrm{NAD}(\mathrm{P}) \mathrm{H}$ :flavin oxidoreductase (HpaC) and catalyze hydroxylation reactions using molecular oxygen as an innocuous oxidant under ambient conditions. ${ }^{13}$ HpaBC monooxygenases play a physiological role in oxidative metabolism of 4-hydroxyphenylacetate. The HpaBC monooxygenase from Pseudomonas aeruginosa PAO1 ( $\mathrm{HpaBC}_{\mathrm{pa}}$ ) reportedly catalyzes the hydroxylation of a variety of aromatic compounds, including $p$-coumaric acid and resveratrol to the corresponding $o$-diphenol compounds. ${ }^{7,13}$ We first explored the

\footnotetext{
${ }^{a}$ Department of Applied Biological Science, Faculty of Science and Technology, Tokyo University of Science, 2641 Yamazaki, Noda, Chiba 278-8510, Japan. E-mail: tfuruya@rs.tus.ac.jp

${ }^{b}$ Daicel Corporation, 2-18-1 Konan, Minato-ku, Tokyo 108-8230, Japan

$\dagger$ Electronic supplementary information (ESI) available. See DOI: 10.1039/c9ra03913a
} 
catalytic potential of $\mathrm{HpaBC}_{\mathrm{pa}}$ for equol hydroxylation using whole-cell assays with $\mathrm{HpaBC}_{\mathrm{pa}}$-expressing E. coli. Reaction conditions previously optimized for resveratrol were employed, with some modifications. ${ }^{7}$ When $(S)$-equol $(10 \mathrm{mM})$ was incubated with the transformed $E$. coli cells in a microtube containing $250 \mu \mathrm{L}$ of reaction mixture, high-performance liquid chromatography (HPLC) analysis exhibited a very small product peak (retention time, $13.2 \mathrm{~min}$ ) in addition to the substrate peak (14.0 min) (Fig. 1). The product peak was not detected in the reaction with $E$. coli cells carrying the empty vector without the $h p a B C_{\mathrm{pa}}$ gene (Fig. 1). However, due to low yield, we could not identify the product.

We next searched for $(S)$-equol hydroxylases using a genome mining approach. A BLAST search of microbial genome sequences performed using the amino acid sequence of $P$. aeruginosa $\mathrm{HpaB}_{\mathrm{pa}}$ identified numerous $\mathrm{HpaB}$ homologues. Interestingly, the genome sequences of Gram-negative Photorhabdus luminescens subsp. laumondii TTO1 and Gram-positive
Rhodococcus opacus B-4 were found to contain three hpaB homologues encoding gene products exhibiting moderate amino acid identity (51-72\%) with $P$. aeruginosa $\mathrm{HpaB}_{\mathrm{pa}}$ (Fig. S1 $\dagger$ ). It was reported that three amino acid residues, Arg100, Tyr104, and His142, were involved in binding the hydroxy group of the substrate 4-hydroxyphenylacetate in the crystal structure of $\mathrm{HpaB}$ from Thermus thermophilus $\left(\mathrm{HpaB}_{\mathrm{tt}}\right){ }^{\mathbf{1 4}}$ These amino acids are conserved in the $\mathrm{HpaB}$ homologues (Fig. S2 $\dagger$ ). In contrast, although Ser197 and Thr198 of $\mathrm{HpaB}_{\mathrm{tt}}$ reportedly interacted with the carboxy group of 4-hydroxyphenylacetate, these amino acids are not conserved (Fig. S2 $\dagger$ ). The divergent amino acid sequences of these putative gene products indicated that they were promising candidates for $(S)$ equol hydroxylation. We therefore focused on the $\mathrm{HpaB}$ homologues of $P$. luminescens $\left(\mathrm{HpaB}_{\mathrm{pl}-1}, \mathrm{HpaB}_{\mathrm{pl}-2}\right.$, and $\left.\mathrm{HpaB}_{\mathrm{pl}-3}\right)$ and $R$. opacus $\left(\mathrm{HpaB}_{\mathrm{ro}-1}, \mathrm{HpaB}_{\mathrm{ro}-2}\right.$, and $\left.\mathrm{HpaB}_{\mathrm{ro}-3}\right)$ (Table $\left.\mathrm{S} 1 \dagger\right)$. As a control, we examined $\mathrm{HpaB}$ from $E$. coli $\mathrm{BL21}(\mathrm{DE} 3)\left(\mathrm{HpaB}_{\mathrm{ec}}\right)$, as this enzyme has been extensively studied (Table $\mathrm{S} 1 \dagger) .^{15}$
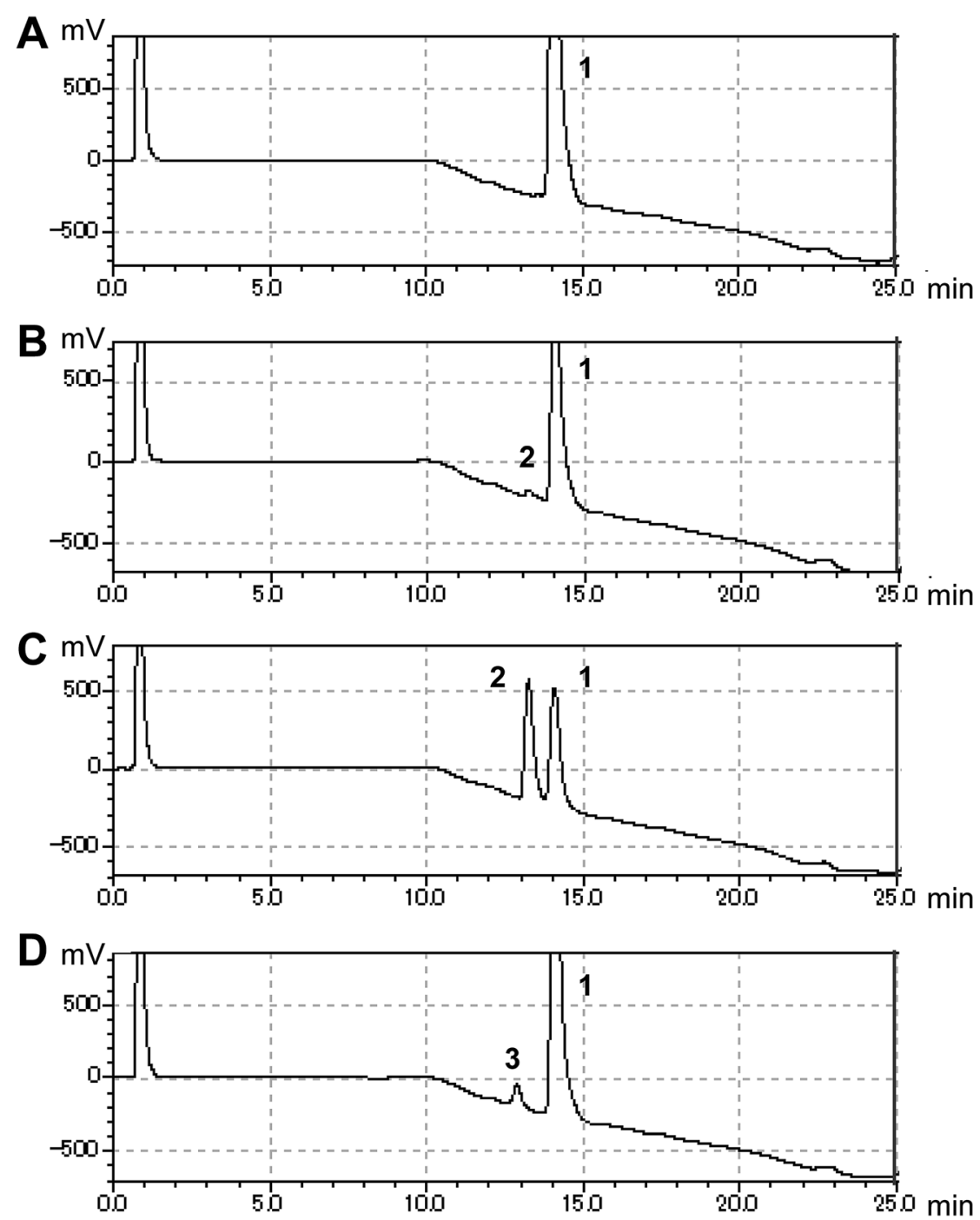

Fig. $1 \mathrm{HPLC}$ analysis of reactions of HpaB enzymes with (S)-equol. E. coli cells carrying the empty vector (A), the $h p a B_{\mathrm{pa}}$ gene (B), the $h p a B_{\mathrm{ro}-3}$ gene (C), or the $h p a B_{\mathrm{pl}-1}$ gene (D) were incubated with (S)-equol. Peaks 1 (at $14.0 \mathrm{~min}$ ), 2 (at $13.2 \mathrm{~min}$ ), and 3 (at $12.8 \mathrm{~min}$ ) were found to correspond to (S)-equol, (S)-3'-hydroxyequol, and (S)-6-hydroxyequol, respectively. 


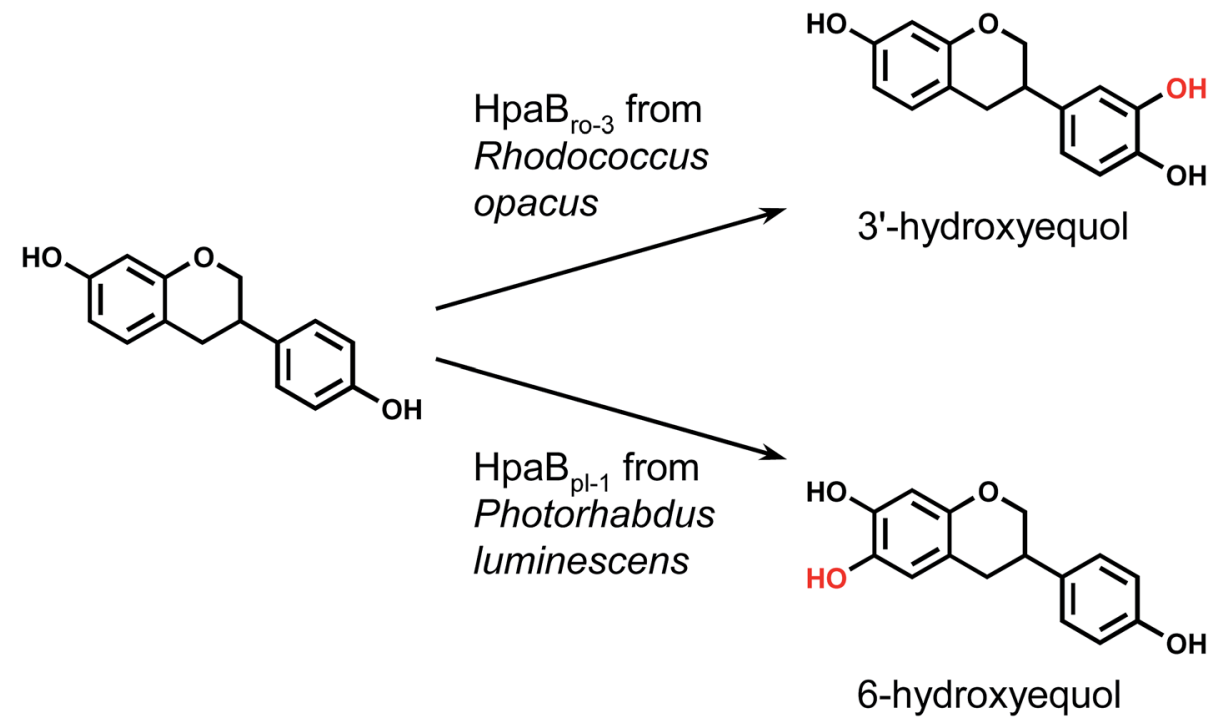

Scheme 1 Regioselective synthesis of hydroxyequols using $\mathrm{HpaB}$ enzymes.

Each $h p a B$ homologue was cloned and co-expressed with $h p a C_{\mathrm{pa}}$ in $E$. coli (Table $\mathrm{S} 1 \dagger$ ). SDS-PAGE analysis revealed major bands corresponding to $\mathrm{HpaB}_{\mathrm{pa}}, \mathrm{HpaB}_{\mathrm{ec}}, \mathrm{HpaB}_{\mathrm{pl}-2}, \mathrm{HpaB}_{\mathrm{ro}-1}$, $\mathrm{HpaB}_{\text {ro-2 }}$, and $\mathrm{HpaB}_{\text {ro-3 }}(\mathrm{ca} .50-60 \mathrm{kDa})$ in the soluble fractions of the transformed $E$. coli cells (Fig. $\mathrm{S} 3 \dagger$ ), whereas $\mathrm{HpaB}_{\mathrm{pl}-1}$ and $\mathrm{HpaB}_{\mathrm{pl}-3}$ were expressed primarily in the insoluble fractions (Fig. S3†). Whole-cell assays using $\mathrm{HpaB}_{\text {ro-3 }}$-expressing E. coli and $(S)$-equol as the substrate revealed a large peak (retention time, $13.2 \mathrm{~min}$ ) upon HPLC analysis (Fig. 1C and $\mathrm{S} 4 \dagger$ ). The product corresponding to this peak was confirmed to be formed from $(S)$-equol via one-oxygen addition based on determination of its mass. Analyses using ${ }^{1} \mathrm{H}$ nuclear magnetic resonance (NMR), ${ }^{13} \mathrm{C}$ NMR, and two-dimensional NMR spectroscopic data (Fig. S5-S8 $\dagger$ ) identified the product as $(S)$-3'-hydroxyequol (Scheme 1). The C-3' position of $(S)$-equol was regioselectively hydroxylated without any detectable by-products by $E$. coli cells expressing $\mathrm{HpaB}_{\mathrm{ro}-3}$.

The production of $(S)$-3'-hydroxyequol was compared among the HpaB homologues (Fig. 2). The highest catalytic activity was exhibited by $E$. coli cells expressing $\mathrm{HpaB}_{\text {ro-3 }}$, with $4.1 \mathrm{mM}$ of $(S)$ 3 -hydroxyequol produced from $10 \mathrm{mM}$ of $(S)$-equol in $24 \mathrm{~h}$, representing 17 times more product than was produced by $E$. coli cells expressing $\mathrm{HpaB}_{\mathrm{pa}}$. $(S)$-Equol was also converted to $(S)$ 3'-hydroxyequol by E. coli cells expressing $\mathrm{HpaB}_{\mathrm{ec}}, \mathrm{HpaB}_{\mathrm{pl}-2}$, and $\mathrm{HpaB}_{\mathrm{ro}-1}$, although the production was low. As equol has a chiral center, both $(R)$-equol and $(S)$-equol are present. Both enantiomers are currently being developed as nutraceutical and pharmacological agents. ${ }^{16}$ We also examined catalytic activities of the HpaB homologues with respect to (R)-equol (Fig. 2). Efficient catalysis of the hydroxylation of $(R)$-equol in addition to $(S)$-equol was observed with $E$. coli cells expressing $\mathrm{HpaB}_{\mathrm{ro}-3}$,

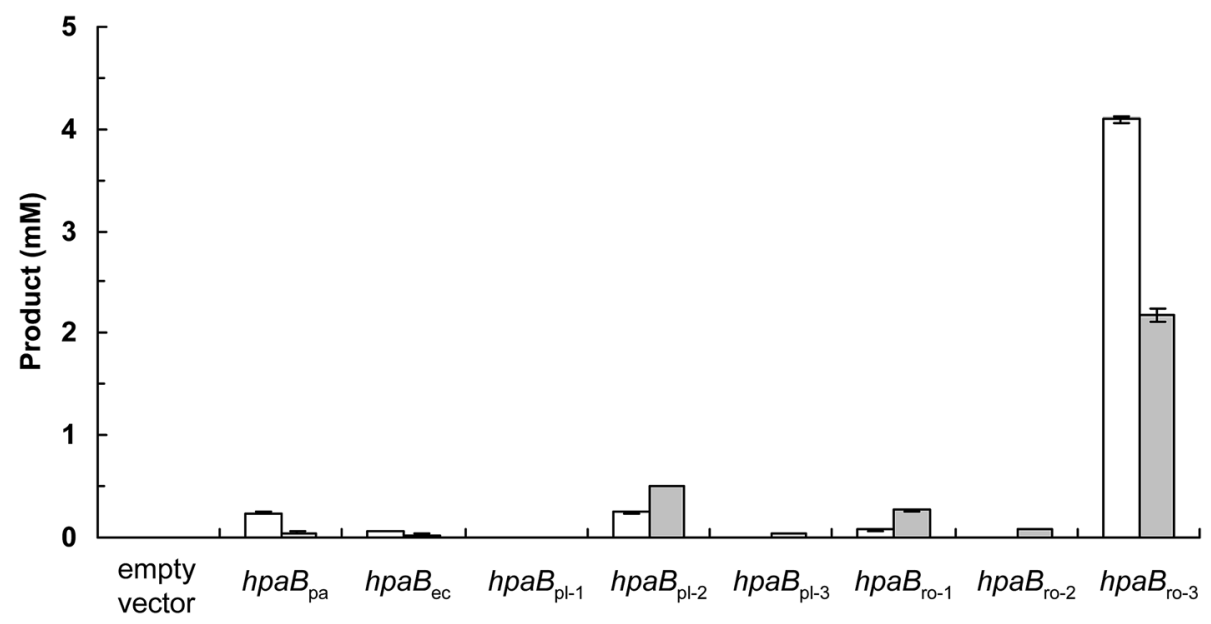

Fig. 2 Activities of HpaB enzymes toward equol. E. coli cells carrying the empty vector or respective hpaB gene were incubated with (S)-equol (white bars) or ( $R$ )-equol (gray bars) for $24 \mathrm{~h}$, and the reaction product $3^{\prime}$-hydroxyequol was quantified using HPLC. Data are the average of three independent experiments, and error bars indicate the standard deviation from the mean. 

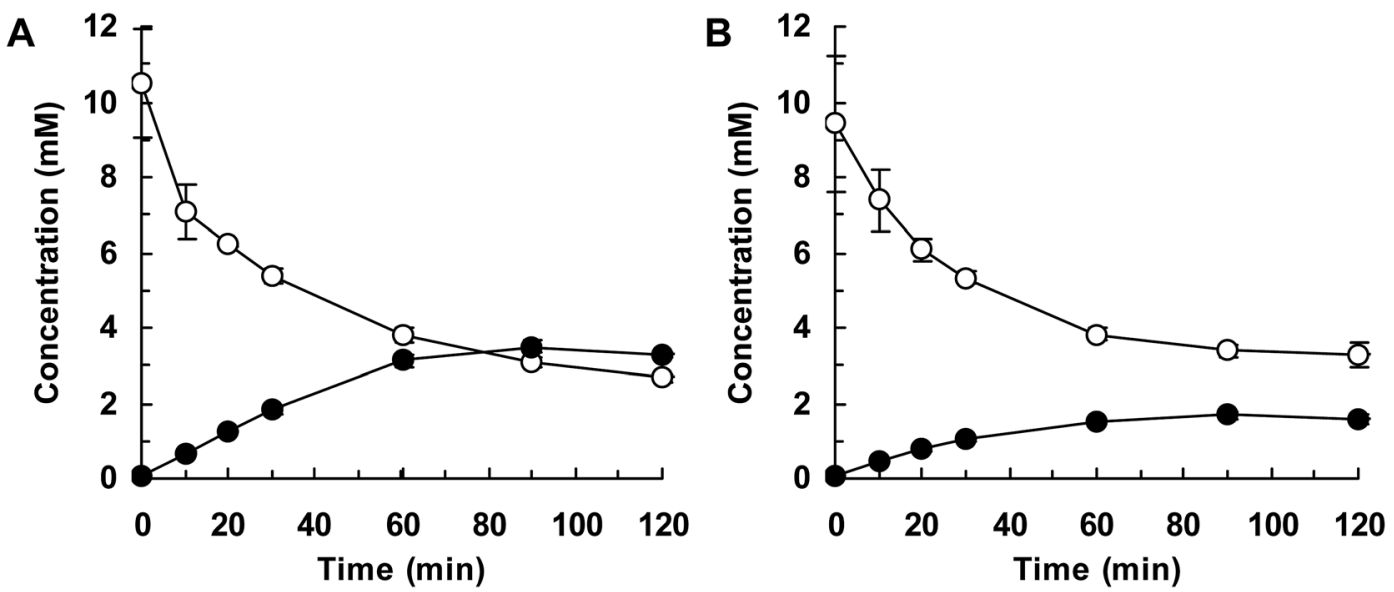

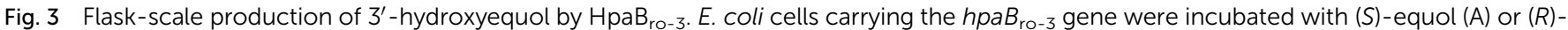
equol (B). Time courses of equol consumption (white squares) and $3^{\prime}$-hydroxyequol production (black circles) are shown. Data are the average of three independent experiments, and error bars indicate the standard deviation from the mean.

with $2.2 \mathrm{mM}$ of $(R)-3^{\prime}$-hydroxyequol produced from $10 \mathrm{mM}$ of $(R)$-equol in $24 \mathrm{~h}$. Interestingly, $\mathrm{HpaB}_{\mathrm{ro}-3}$ converted $(S)$-equol more efficiently than $(R)$-equol in whole-cell reactions, whereas $\mathrm{HpaB}_{\mathrm{pl}-2}$ exhibited substrate preference for $(R)$-equol over $(S)$ equol.

HPLC analyses revealed that the reaction of $\mathrm{HpaB}_{\mathrm{ec}}$ with $(S)$ equol generated a small peak with a retention time of $12.8 \mathrm{~min}$ in addition to a peak eluting at $13.2 \mathrm{~min}$ (corresponding to $(S$ )$3^{\prime}$-hydroxyequol) (Fig. S4 $\dagger$ ). Notably, the reaction of $\mathrm{HpaB}_{\mathrm{pl}-1}$ with $(S)$-equol generated a relatively large peak eluting at $12.8 \mathrm{~min}$, without any detectable by-products (Fig. 1D and $\mathrm{S} 4$ †). $\mathrm{HpaB}_{\text {ro-2 }}$ also generated a peak at the same retention time, which was smaller than that generated by $\mathrm{HpaB}_{\mathrm{pl}-1}$ (Fig. S4 $\uparrow$ ). Although $\mathrm{HpaB}_{\mathrm{pl}-1}(c a .50 \mathrm{kDa})$ is largely insoluble in $E$. coli cells, solubility increases upon co-expression with the chaperonin GroEL and the cochaperonin GroES (Fig. S9†). In experiments using $E$. coli cells transformed in this manner, a compound corresponding to the peak eluting at $12.8 \mathrm{~min}$ was produced and confirmed to be formed from (S)-equol via one-oxygen addition based on determination of its mass. Furthermore, analysis by NMR spectroscopy (Fig. S10-S13†) identified the product as (S)-6-hydroxyequol (Scheme 1). The C-6 position of $(S)$-equol was regioselectively hydroxylated by $E$. coli cells expressing $\mathrm{HpaB}_{\mathrm{pl}-1}$.

Finally, we attempted flask-scale production of $3^{\prime}$ - and 6hydroxyequols using $E$. coli cells expressing $\mathrm{HpaB}_{\text {ro-3 }}$ and $\mathrm{HpaB}_{\mathrm{pl}-1}$, respectively. Equol was incubated with respective $\mathrm{HpaB}$ whole-cell catalyst in a $500 \mathrm{~mL}$ flask containing $20 \mathrm{~mL}$ of reaction mixture. The time course of equol conversion is shown in Fig. 3 and 4 . $\mathrm{HpaB}_{\mathrm{ro}-3}$-expressing E. coli cells produced $3.5 \mathrm{mM}\left(0.90 \mathrm{~g} \mathrm{~L}^{-1}\right)$ of $(S)-3^{\prime}$-hydroxyequol and $1.7 \mathrm{mM}(0.44 \mathrm{~g}$ $\mathrm{L}^{-1}$ ) of $(R)$-3'-hydroxyequol from $10 \mathrm{mM}(S)$-equol and $(R)$-equol, respectively, only in $90 \mathrm{~min}$ (Fig. 3). The rate of equol hydroxylation by $E$. coli cells expressing $\mathrm{HpaB}_{\mathrm{pl}-1}$ was low compared with rate of equol hydroxylation by $E$. coli cells expressing $\mathrm{HpaB}_{\mathrm{ro}-3}$ (Fig. 4). Nonetheless, $\mathrm{HpaB}_{\mathrm{pl}-1}$-expressing E. coli cells
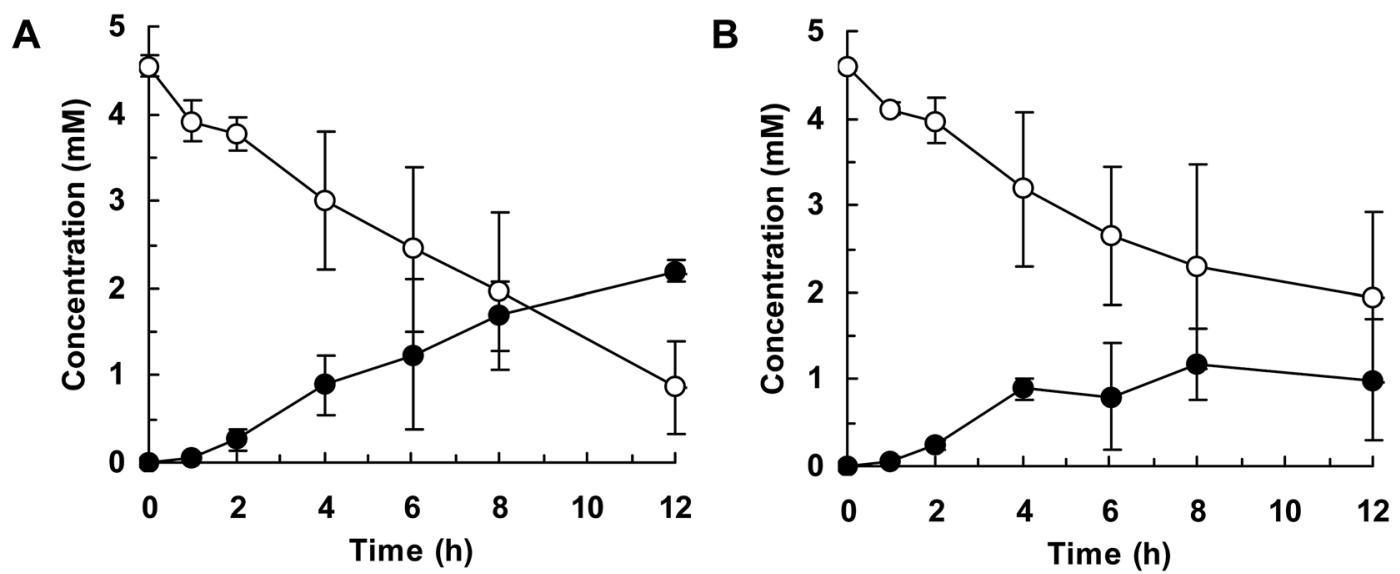

Fig. 4 Flask-scale production of 6-hydroxyequol by HpaB pl-1. E. coli cells carrying the hpaB $B_{\mathrm{pl}-1}$ gene were incubated with (S)-equol (A) or (R)equol (B). Time courses of equol consumption (white squares) and 6-hydroxyequol production (black circles) are shown. Data are the average of three independent experiments, and error bars indicate the standard deviation from the mean. 
produced $2.2 \mathrm{mM}\left(0.57 \mathrm{~g} \mathrm{~L}^{-1}\right)$ of $(S)$-6-hydroxyequol and $1.0 \mathrm{mM}$ $\left(0.26 \mathrm{~g} \mathrm{~L}^{-1}\right)$ of $(R)$-6-hydroxyequol from $5 \mathrm{mM}(S)$-equol and $(R)$ equol, respectively, in $12 \mathrm{~h}$.

\section{Conclusions}

In this study, we developed a one-step, product-selective approach for synthesizing $3^{\prime}$ - and 6-hydroxyequols from equol using monooxygenases of the HpaBC family. To the best of our knowledge, this is the first report describing enzymes that catalyze the hydroxylation of equol. Previous metabolic studies have suggested that $(S)$-equol is further metabolized in mammals. ${ }^{\mathbf{1 1}, \mathbf{1 7}}$ Hydroxyequols synthesized using the approach presented here might be useful in studies evaluating biological activity, including the toxicity of potential metabolites, as well as in investigations of structure-activity relationships. In addition, these hydroxyequols and their derivatives could have applications as nutritional supplements and pharmaceuticals. Although typical HpaB enzymes from $P$. aeruginosa and $E$. coli exhibited only low catalytic activity for equol, we identified two novel HpaB homologues exhibiting high activity and differing regioselectivity for equol using a genome mining approach. Although typical HpaB enzymes have been extensively studied, few studies appear to have examined potential exploitation of their homologues. The results of this study suggest that other $\mathrm{HpaB}$ homologues exhibiting useful catalytic activities are present in nature. Further investigations will therefore focus on more-intensive screening for enzymes exhibiting greater activity and different selectivity for equol and other flavonoids for the synthesis of valuable polyphenols.

\section{Conflicts of interest}

There are no conflicts to declare.

\section{Notes and references}

1 J. H. Mitchell, P. T. Gardner, D. B. McPhail, P. C. Morrice, A. R. Collins and G. G. Duthie, Arch. Biochem. Biophys., 1998, 360, 142-148; C. E. Rüfer and S. E. Kulling, J. Agric. Food Chem., 2006, 54, 2926-2931.

2 T. D. Lund, D. J. Munson, M. E. Haldy, K. D. Setchell, E. D. Lephart and R. J. Handa, Biol. Reprod., 2004, 70, 1188-1195; R. S. Muthyala, Y. H. Ju, S. Sheng, L. D. Williams, D. R. Doerge, B. S. Katzenellenbogen, W. G. Helferich and J. A. Katzenellenbogen, Bioorg. Med. Chem., 2004, 12, 1559-1567; K. D. Setchell, N. M. Brown and E. Lydeking-Olsen, J. Nutr., 2002, 132, 3577-3584.

3 T. Aso, S. Uchiyama, Y. Matsumura, M. Taguchi, M. Nozaki, K. Takamatsu, B. Ishizuka, T. Kubota, H. Mizunuma and
H. Ohta, J. Women's Health, 2012, 21, 92-100; A. Oyama, T. Ueno, S. Uchiyama, T. Aihara, A. Miyake, S. Kondo and K. Matsunaga, Menopause, 2012, 19, 202-210; Y. Tousen, J. Ezaki, Y. Fujii, T. Ueno, M. Nishimuta and Y. Ishimi, Menopause, 2011, 18, 563-574; T. Usui, M. Tochiya, Y. Sasaki, K. Muranaka, H. Yamakage, A. Himeno, A. Shimatsu, A. Inaguma, T. Ueno, S. Uchiyama and N. Satoh-Asahara, Clin. Endocrinol., 2013, 78, 365-372.

4 F. Rafii, Metabolites, 2015, 5, 56-73; K. D. Setchell and C. Clerici, J. Nutr., 2010, 140, 1355S-1362S; J. P. Yuan, J. H. Wang and X. Liu, Mol. Nutr. Food Res., 2007, 51, 765781.

5 A. B. Alvero, M. Kelly, P. Rossi, A. Leiser, D. Brown, T. Rutherford and G. Mor, Future Oncol., 2008, 4, 475-482; S. Mahoney, F. Arfuso, M. Millward and A. Dharmarajan, Cancer Cell Int., 2014, 14, 110.

6 M. P. Marques, J. Med. Chem., 2003, 46, 5395-5401; C. Siquet, F. Paiva-Martins, J. L. Lima, S. Reis and F. Borges, Free Radical Res., 2006, 40, 433-442.

7 T. Furuya and K. Kino, Tetrahedron Lett., 2014, 55, 28532855; T. Furuya, M. Sai and K. Kino, Biosci., Biotechnol., Biochem., 2016, 80, 193-198; T. Furuya, M. Sai and K. Kino, J. Biosci. Bioeng., 2018, 126, 478-481.

8 A. Arora, M. G. Nair and G. M. Strasburg, Arch. Biochem. Biophys., 1998, 356, 133-141.

9 P. G. Lee, J. Kim, E. J. Kim, S. H. Lee, K. Y. Choi, R. J. Kazlauskas and B. G. Kim, ACS Chem. Biol., 2017, 12, 2883-2890.

10 G. Di Nardo and G. Gilardi, Int. J. Mol. Sci., 2012, 13, 1590115924.

11 C. E. Rüfer, H. Glatt and S. E. Kulling, Drug Metab. Dispos., 2006, 34, 51-60.

12 S. J. Gharpure, A. M. Sathiyanarayanan and P. Jonnalagadda, Tetrahedron Lett., 2008, 49, 2974-2978.

13 T. Furuya and K. Kino, Appl. Microbiol. Biotechnol., 2014, 98, 1145-1154; T. Heine, W. J. H. van Berkel, G. Gassner, K. H. van Pée and D. Tischler, Biology, 2018, 7, E42.

14 S. H. Kim, T. Hisano, K. Takeda, W. Iwasaki, A. Ebihara and K. Miki, J. Biol. Chem., 2007, 282, 33107-33117.

15 W. Chen, J. Yao, J. Meng, W. Han, Y. Tao, Y. Chen, Y. Guo, G. Shi, Y. He, J. M. Jin and S. Y. Tang, Nat. Commun., 2019, 10, 960; J. A. Jones, S. M. Collins, V. R. Vernacchio, D. M. Lachance and M. A. Koffas, Biotechnol. Prog., 2016, 32, 21-25; M. A. Prieto and J. L. Garcia, J. Biol. Chem., 1994, 269, 22823-22829.

16 K. D. Setchell and C. Clerici, J. Nutr., 2010, 140, 1363S-1368S. 17 R. J. Schwen, L. Nguyen and R. L. Jackson, Food Chem. Toxicol., 2012, 50, 2074-2083. 